\title{
Bir Sosyal Sorumluluk Projesi ve Ülke Rehberi Çalışması: Hüseyin Orak’ın Türkiye Kılavuzu Çalışması İçinde Antalya
}

\author{
A Social Responsibility Project and Country Guide Study: \\ Antalya in The Turkey Guide Study of Hüseyin Orak
}

\begin{abstract}
Zakir AVŞAR* Mehmet YÜKSEL ${ }^{* *}$

Özet: Türkiye Kılavuzu, 1946 yılında Hüseyin Orak adlı bir işadamı tarafından tüm servetini harcamak pahasına hazırlanmış, değeri anlaşılamamış Türkiye'nin bütün illerini kapsayan ilk turizm ve tanıtma rehberidir. Beş cilt olarak tasarlanan ancak ilk cildin yayımı sonrası ilgi görmemesi ve işadamının bu çalışma dolayısıyla maruz kaldığı ağır borç yükü nedeniyle iflası neticesinde tamamlanamayan bu çalışmanın birinci cildi içinde yer alan 14 vilayetten birisi de Antalya'dır. Antalya ilinin 1945 sonrası ekonomik, sosyal, kültürel, tarihi ve turistik görünümünü yansıtan bu çalışma şehir tarihi ve araştırmaları bakımından özgün bir değer taşımaktadır. Şu ana kadar akademik anlamda hiç değerlendirilmemiş, ele alınmamış olan bir sosyal sorumluluk projesi olarak gerçekleştirilen bu kitap çalışması ve özellikle Antalya ile ilgili kısmı hakkında bu makale çerçevesinde bilgi aktarılacaktır.
\end{abstract}

Anahtar Sözcükler: Tanıtma, Şehir araştırmaları, Şehir tarihi, Türkiye Kılavuzu, Sosyal sorumluluk projesi

Abstract: Türkiye K1lavuzu, the Guide to Turkey, prepared in 1946 by the businessman Hüseyin Orak at the cost of all his wealth was not appreciated at the time, but was the first tourism and information guide planned to include all the provinces of Turkey. Antalya was one of the fourteen provinces that form the first volume of this study, which was planned as five volumes but which remained incomplete because the first volume failed to attract sufficient attention and sales following its publication, causing the bankruptcy of Hüseyin Orak due to the debts incurred during the course of its publication. This work records the economic, social, cultural, historical and touristic views of post-1945 Antalya, and has a great value in terms of city history and research. Within the framework of this article, information concerning this book, which was produced as a social responsibility project and which has never been academically reviewed or discussed, and especially concerning the section on Antalya, is related.

Keywords: Information, City research, City history, Turkey Guide, Social responsibility project

Türkiye Kılavuzu adlı çalışmanın hazırlayıcısı ve sahibi olan Hüseyin Hilmi Orak, 01.07.1897 tarihinde şimdi Romanya sınırları içinde kalan Dobruca Bölgesi’ndeki Tulca ilinin Babadağ kasabasında doğmuş, Balkanlardaki karışıklıklar neticesinde 1910 yılında ailesinin bazı fertleriyle birlikte önce İstanbul'a daha sonra da Eskişehir'e göçmüştür. İstanbul'daki amcasının 1srariyla 22 Kanun-1 Evvel 1331 (4 Ocak 1916) tarihinde Kara Harp Okulu'na (Harbiye) kaydolmuş; 25 Nisan 1332 (8 Mayıs 1916) tarihinde mezun olarak Irak Cephesi’nde 13. Kolordu 18. Alay 3. Tabur 9. Bölük'e tayin olmuştur. 1 Teşrin-i Evvel (1334) tarihinde Basra' da İngilizlere esir düşmüş, iki yıl Hindistan'daki esir kamplarında kaldıktan sonra 19 Teşrin-i Evvel (19 Ekim

\footnotetext{
* Prof. Dr., Gazi Üniversitesi, İletişim Fakültesi, Radyo Televizyon ve Sinema Bölümü, Ankara, zakiravsar@gmail.com

** Prof. Dr., Gazi Üniversitesi, İletişim Fakültesi, Gazetecilik Bölümü, Ankara, msina@gmail.com
} 
1918) tarihinde İstanbul'a geri dönmüş ve 25 Teşrin-i Evvel (25 Ekim 1920) tarihinde terhis edilmiştir. Ancak, İstiklal Harbi'nin başlaması üzerine 31 Kanun-1 Sani (31 Ocak 1921) tarihinde yeniden askere alınmış, 14. Fırka Muhabere Takım Zabitliği görevine atanmıştır. 7 Ağustos 1323 tarihinde de terhis olmuştur. 1926 yılında 15 Nisan-30 Mayıs tarihleri arasında bir kez daha askere alınmış ve birkez daha terhis olmuştur. 27 Mart 1928 tarihinde S.11937 numaralı İstiklal Madalyası ile taltif edilmiştir. İkinci Dünya Savaşı'nın başlaması üzerine 5 Ağustos 1940 tarihinde bir kez daha askere alınmış ve 5 Ekim 1941 yılında yine terhis olmuştur (MSB, 5 Ekim 2011). Hayata asker olarak başlayan, Birinci Dünya Savaşı, İstiklal Harbi ve İkinci Dünya Savaşları'nda subay olarak askerlik görevini ifa eden Hüseyin Orak, kısa bir dönem Türkiye'nin tanınmış büyük sanayici ve işadamı Vehbi Koç ile ortaklık kurmuş ticaret ve sanayi alanlarında mühim başarıları olan bir işadamıdır (Bkz. ATO, 363 No.lu dosya).

Kendisini Türkiye Kılavuzu adlı böyle bir çalışmaya iten neden çok ilginçtir (Yazarlar, Hüseyin Orak ve Türkiye Kılavuzu isimlerine ilk kez Orhan Karaveli’nin, Görgü Tanığ -Bir Gazeteci'nin Sıradışı Anıları. İstanbul: Pergamon Yayınları, 2006., adlı eserinde rastlamış, bu ilginç isimle ilgili çalışmayı başlatmak için yazarla temasa geçerek yüzyüze bir görüşme gerçekleştirmişlerdir (İstanbul, 14 Haziran 2011). Karaveli, Orak'ın babasının arkadaşı olduğunu, ancak hem babasının hem de Orak'ın hayatta olmadığını, Orak'ın geriye kalanları olup olmadığını bilmediğini belirtmiş, bunun üzerine yazarlar Orak'ın Ankara Ticaret Odası'nda tüccar kaydı olup olmadığını araştırma cihetine giderek, ATO'daki dosyasına, akabinde oradaki verilerden hareketle ailesinin yaşayan fertlerine ulaşmışlardır. Keza askerlik hayatı ile ilgili veriler de MSB ile yazışmak suretiyle temin edilmiştir. Başta Yazar Orhan Karaveli, kızı Ayşe Sahavet Özbay olmak üzere, Hüseyin Orak'la ilgili bilgilere ulaşılmasında pek çok kişinin, kurumun emeği vardır. Kendilerine şükranlarımızı sunarız). 1936 yılında sınıflarını başarıyla geçen 11 yaşındaki kızı Fatma Zekâvet ve 9 yaşındaki kızı Ayşe Sahavet'in, karne hediyesi olarak İstanbul'a yakınlarını ziyarete gitme istekleri üzerine, onları o günlerde TCDD'nin kombine bilet uygulamasından hareketle, tüm yurdu gezmeleri ve nihayetinde İstanbul'a ulaşmaları konusunda ikna etmiştir. Seyahati ilginç kılan iki kız kardeşin yanına 7 yaşındaki oğlu Yılmaz'1 da katarak, yanlarında kendisi ve anneleri olmaksızın bu "maceraya" razı etmesidir. O günlerin şartlarında tüm dünya bir ateş çemberinde iken, ikisi kız, üç küçük çocuğun trenle yurt seyahatine çıkmaları büyük bir ilgi görmüş, "küçük seyyahlar" gittikleri yerlerde adeta halk kahramanları gibi karşılanmışlar, valiler, kaymakamlar, belediye başkanları ve şehirlerin önde gelenleri çocuklarla hususi olarak ilgilenmişlerdir. Yaklaşık iki buçuk ay süren bu yurt seyahati sonrasında çocukları Başbakan İsmet İnönü'de kabul etmiş ve seyahat esnasında tuttukları defteri şu sözlerle imzalamıştır: "Küçük seyyahlar tebrik ettim. Seyahat sevmek bir memleket için çok eyi (iyi) bir şey, teşvik olunacak bir arzudur. 12.09.1936” (Orak, 1946, numarasız sayfa).

Atatürk'e, devrimlere inanmış bir eski asker, işadamı olan Hüseyin Orak, çocuklarının trene binmesinden önce seyahat anılarını kaleme almaları için ellerine tutuşturduğu not defterine (Söz konusu anı defterine başta Başbakan İsmet İnönü olmak üzere, gittikleri her yerin mahalli ve mülki erkanı seyahatin anlam ve önemini içeren yazılar yazmış, çocuklar kendi gördüklerini kaydetmişlerdir, ancak bu notlardan sadece Hüseyin Orak'ın ve İnönü'nün yazdıkları Türkiye Kılavuzu adlı çalışmaya aktarıldığ Fatma Zekavet (Orak) hanımın hususi evrakları arasında bulunamamıştır).Temmuz 1936 günü duygularını şu cümlelerle yansıtır: "Sevgili Yavrularım, yurdunu tanımayan, bilmeyen kimseden bir fayda beklenemez. Bir kiracının bile oturduğu evin içinde ve etrafinda neler vardır, bunu bilmesi lazımdir. Nerde kaldı ki siz, kendi evinizin (yurdunuzun) öz sahiplerisiniz. Onu iyice tanımazsanız, sahibi olamazsınız. Ona yabancı kalırsanız, size gülerler (...) Sevgili yurdumuzda neler var, yurdun dört bucağındaki kardeşlerimiz ne halde, büyüklerimiz neler yapmışlar, ilerde sizin de büyüyünce neler yapmanız lazım, atalarımız bize neler bırakmışlar, bunları bilerek, yurt 
bilginizi artırarak döneceksiniz (...)" (Orak, 1946, 9). Orak'ın yukarıda zikredilen yaklaşımında; modernleşme ve ulus-devletleşme sürecinde ekonomi ve ticaretle yakından ilgili bir kimsenin zihniyet dünyasını, yani yükselmekte olan burjuva dünya görüşünü ve bu bağlamda gelişen bireycilik ve milliyetçilik gibi yeni değerleri görmek mümkündür. Böylece, geleneksel toplum yapısında modern topluma geçiş sürecinde yeni bir değerler sisteminin ve zihniyet dünyasının Orak'ın kişiliğinde ne denli içselleştirilmiş olduğunu anlıyoruz (Yüksel, 2004,71).

Orak, çocuklarına yurt gezilerinin verimli geçmesi için, yapması gerekenleri de belirtir. Mutlaka gittikleri yerlerde memleketin büyüklerini ziyaret ederek onlardan bilgiler istemelerini, elde ettikleri bilgileri defterlerine kaydetmelerini, onların imzalarını almalarını ister: “... Bu defter size yurdun büyük bir hatırası ve ilerde sizin için bir rehber olacaktır” (Orak, 1946, 9).

Gezi güzergâhı Ankara Tren Garı'ndan başlayarak, Kırıkkale, Kayseri, Sivas, Adana, Mersin, Malatya, Elazı̆̆ Diyarbakır, Samsun, İstanbul Haydarpaşa olarak gerçekleşir. Çocuklar her gittikleri yerde en az üç gün konaklarlar. Konaklamalar ve gezi programları Hüseyin Orak'ın iş arkadaşları ve mahalli ve mülki erkân tarafından ayrıntılı olarak düşünülmüştür. Çocuklara hiçbir sıkıntı çektirilmemesi için olağanüstü bir gayret gösterilir. Jandarma ve polise şifre telgraflarla güvenlik önlemleri almaları emredilir. Zaten halkın sevgilisi haline gelen çocuklar, babaları tarafından kendilerine verilen harçlıkları bile harcayacak yer bulamazlar, hatta tüm ülkeden kendilerine taşıyamayacakları kadar çok ve güzel hediyeler verilir (A. Sahavet Özbay ile yapılan görüşme, 24 Haziran 2011). Gazeteler çocuklardan bahseder, gittikleri yörelerde haber olurlar: "Yalnız Başlarına İki Küçük Kardeş Yurdu Geziyorlar" (Kurun, 28 Temmuz 1936). Adana'da Türksözü Gazetesi'ni de ziyaret ederler, gazete, çocukların ellerinde 5 Temmuz 1936 tarihinde alınmış ikişer aylık halk ticaret biletleriyle ülkeyi gezdiklerini, babalarının kendilerine 50 liralık harçlık verdiğini, Ankara, Kırıkkale, Sivas, Turhal, Samsun, Mersin ve Adana'ya uğradıklarını, Malatya, Elaziz (Elazığ) ve Diyarbekir'e (Diyarbakır) gideceklerini, Adana'da Tüccar Ahmet Muhtar'ın evinde misafir olduklarını şehrin görülecek yerlerini gezdiklerini yazmaktadır (Türksözü, 25 Temmuz 1936).

Çocukların son durağı İstanbul olur. İstanbul'da Heybeliada'da Başbakan İsmet İnönü'yü ziyaretle bu macera son bulur. Ancak, çocukların bu heyecan dolu, ilginç gezilerinin son bulması Hüseyin Orak'ın bütün hayatını etkileyecek gelişmelerin önünü kesemez.

Hüseyin Orak, çocuklarını bu geziye çıkarırken 1srarla ülkeyi tarihi, kültürel, turistik, ekonomik, sosyal bakımlardan tanıtan bir kılavuz (rehber) kitap arar. Ne var ki, bir türlü böyle bir çalışmaya ulaşamaz. Çocuklarının gezisi sonrası hızla gelişen siyasal krizler ve akabinde II. Dünya Savaşı ile birlikte askere alınmasıyla bir süre işinden de uzak kalır. Ancak 1945 yılının başlarında büyük kızının İstanbul Diş Hekimliği Fakültesi'ni kazanması üzerine, onun ders kitaplarını ararken aklına yine bu türden bir rehber basılıp basılmadığı hususu gelir. Tüm aramalarına/araştırmalarına rağmen bulamaz. Piyasada illeri tanıtan ne kadar çalışma varsa toparlar. Hatta yabancı dillerdeki yayınları da getirtir. Bir türlü istediği nitelikte bir çalışmaya ulaşamaz. Bunu bir sosyal sorumluluk projesi ve yurduna karşı bir görev olarak kabul ederek, kendisi finanse eder, hazırlamaya/hazırlatmaya karar verir.

Hüseyin Orak, her şeyden önce bir tüccar olup toplumun ekonomi ve ticaret hayatı bakımından yazılı bilginin ve kültürün ne kadar hayati olduğunun bilincindedir. Yine bu konumu nedeniyle iletişim ve ulaşım imkanlarının geliştirilmesi ihtiyacının da farkındadır. Çünkü, ekonomik ve ticari gelişmelerle birlikte, iletişim ve ulaşım imkanlarındaki ilerlemeler, ülke üzerindeki hükümet ve yönetim işlerinin koordinasyonunu kolaylaştırarak modernleşme çabasındaki ulusdevlet yapısının gelişip serpilmesi için uygun ortamı yaratacaktır (Giddens, 1994, 147). Osmanlı'dan Cumhuriyet'e uzanan modernleşme sürecinde bir ulusal ekonomi yaratma, 1908'de başladı ve hızlanarak devam etti. Bu çerçevede ulusal pazarı bütünleştirmek ve üretilen mahsullere talep yaratmak için bir karayolu ve demiryolu şebekesi inşa edilmeye başland. 1915'te taşıt 
trafiğine uygun 30 bin kilometre demiryolu vaat edildi. İş hayatını kolaylaştırmak için posta adresi olarak sokaklara isim verilirken evler de numaralandırılmaya başlandı. Telefon tesisatları kuruldu. Ülke dahilinde seyahat ve iletişimi kolaylaştırmak için iç pasaport uygulaması kald1rıldı (Ahmad, 1999, 59-60). Bu yöndeki çabalar, Cumhuriyet Dönemi’nde de artarak sürdürüldü.

Topladığı Türkçe ve yabancı dildeki seyahatname, gezi yazısı, ekonomik ve sosyal, coğrafi, kültürel ve tarihsel analiz türü eserlere ilişkin olarak eser sahiplerinin gezip gördükleri yerleri kendi duygu ve düşüncelerine, şahsi uzmanlıklarına göre yazmış olmalarından ve "birbirlerini tutmayan pek çok görüş ortaya çıkmış olması ile bunlar arasından gerçek, doğru olanları ayırmanın pek güç olmasından" dolayı eleştirir (Orak, 1946, 11). Yine, eser sahiplerinin kendilerinden öncekilerin eserlerinden yola çıkarak, bazı hakikatleri tespit etmelerine rağmen sınırlı kaldıklarını, bazılarının ise yalnızca eski devirlerin parlaklıklarını ve yaşamış milletlerin eriştikleri medeniyetin şaşaasını anlatmak, eski eserler üzerine araştırmalar yapmakla birlikte bugünü tamamen unuttuklarını; keza eserlerinin de tarih, arkeoloji, jeoloji incelemeleri hüviyetini taşıdı$\breve{g} ı n ı$ belirtir.

Hüseyin Orak hazırlamayı arzu ettiği çalışmayı, "yurdun her sınıf halkına hitap etsin, aziz vatanımızın tarih boyunca geçirdiği safhalarını, kültür ve sosyal sahalarda eriştiği seviyesini, tabii ve sınai varlıklarını, ekonomi durumunu, dünün ve bugünün yaşayış farklarını, Cumhuriyet devrinin memleket alanında feyizli tesislerini el ile tutulur ve göz ile görülür bir şekilde hakiki veçhesiyle göstersin" (Orak 1946, 12) sözleriyle tarif eder. Burada, Tanzimat Dönemi’nden başlayarak Cumhuriyet'e de intikal eden Aydınlanma düşüncesinin ve Pozitivist bilim anlayışının tezahürlerini görebiliriz. Aydınlanma, halka bilgi götürme, gözleri batıl inançla kaplı olanlara kesin bir bakış açısı kazandırma, ilerlemeye zemin oluşturacak doğru bilgiye ulaşma gibi güçlü dürtülere sahip bir düşünce hareketi olarak tanımlamak mümkündür (Bauman, 1996, 91). Cumhuriyet Döneminde giderek gelişen ekenomik hayatın ve ulus-devlet yapısının ve bu devletin yurttaşlarının ihtiyaç duyduğu net bilgiyi ancak bilim sağlayabilirdi. Bir analiz ve düşünce yöntemi olarak Pozitivist yaklaşım, deney ve araştırma yoluyla kesin bilgiye ulaşılabileceği varsayımına dayanır. Bu sayede batıl inançlardan ve doğmatik düşüncelerden insanların kurtarılarak daha uygar ve ileri bir toplum aşamasına varılabileceğine inanılır (Erdoğan, 2000, 245). Giderek gelişen ekonomik ve ticari ilişkilerin, ulus-devlet çatısı altında bir araya getirilen milyonlarca insanın ihtiyaç ve sorunlarının kavranarak geleceğin planlanması ve inşası, bütün bu sorunların üstesinden gelme amacında olan modern ulus-devletin yönetilmesi, hiç kuşkusuz bilimsel bilgiye olan acil ihtiyacı ortaya çıkarıyordu.

Orak, bu hususa ilişkin fikrini ilk olarak Yapı Sanat Enstitüsü Müdürü ve yakın dostu eğitimci Mitat Artun'a (Mitat Artun,1943 yılında Maarif Vekaleti Yap1 Enstitüsü Müdürlüğü görevine getirilmiş, bu görevi 1959 yılına kadar sürdürmüştür) açar. Eserin adının "Türkiye Kılavuzu" olmasına da bu düşünceler doğrultusunda birlikte karar verirler. Öncelikle kılavuzun oluşturulması için bir program tespit ederek oluşturulacak gezici gruplar için soru kağıtları hazırlanıp bastırılır. Her il için dosyalar oluşturulur. Yerli yabancı dillerden bir kütüphane, çalışacak kişiler için ofis hazırlanır. Çalışma sistematiği bakımından da, yurdu gezecek ekipler yola çıkarılarak her ile ait her alanda yazılmış olan eserleri toplamak, bunları genel eserlerdeki bilgilerle karşılaştırmak, yabancı dillerdeki Türkiye'yi ilgilendiren eserleri Türkçe'ye çevirmek ve bütün bunları programa uygun hale getirerek yazmak gibi bir yöntem benimsenir. Bunları yapmak için de ihtisas sahibi yetkin kişilerden oluşan 10 kişilik bir yazı heyeti meydana getirilerek ortak çalışma yürütülmesi düşünülür. Yurdu 10 bölgeye ayırıp her bir uzman kişiye ve yanlarına alacakları yardımcıya bir bölge verilecektir. Bu kişiler bizzat bölgelere gidecekler ve yerinde tetkik yapacaklardır. Bunun için de, alanlarında saygın profesör, doçent, öğretmen zatlardan müteşekkil bir heyetle her gece toplantılar başlar. İki ay kadar süren bu toplantılardan uygulamaya ilişkin görüş ayrılıkları nedeniyle bir netice alınamaz. Kendi ifadesiyle bu kişilere 
yapacakları işin bir "Memleket borcu olduğunu" hatırlatması bile bu müşterek gaye etrafında birleştirmeye yetmez (Orak, 1946, 13).

Kızı A. Sahavet Özbay kendisiyle yüz yüze yapılan görüşmede bu satırların yazarına, babasının o günlerde zamanın şartlarında çok önemli ve büyük sayılabilecek bir bütçe olan 50 bin lirayı Türkiye Kılavuzu'nun başlangıç sermayesi olarak ayırdığını belirtmektedir. Buna ek olarak, şirketinin olduğu binada bir kat, toplantı ve çalışmalarını gerçekleştirmek amacıyla düzenlenmiş, özel toplantı ve çalışma masaları yaptırılmıştır. Babasının çalıştıramadığı ilk ekipte yer alan isimlerin o günün en tanınmış bilim simaları olduğunu, çoğunlukla Siyasal Bilgiler Okulu'nun (A.Ü. SBF) hocalarından oluştuğunu hatırladığını belirtmiştir (A. Sahavet Özbay ile yapılan görüşme, 24 Haziran 2011).

İlk heyetin başarısızlığı Hüseyin Orak'1 pes ettirmez, tersine arkadaşı Mitat Artun'la birlikte tanınmış kişilerle çalışmaktan vazgeçerek, özellikle ve çoğunlukla Muallim Mektebi'nin (şimdiki Gazi Üniversitesi Eğitim Fakültesi) hocalarından oluşan yeter bilgide, çalışkan, mütevazi, sebatkar bir yazı heyeti oluşturulmasına karar verirler.

\section{1) Türkiye Kılavuzu Nasıl Hazırlandı?}

Türkiye Kılavuzu hazırlık çalışmaları için öncelikle, bir çalışma programı yapılır. Çalışmaya katılacaklara, gidecekleri yerlerde hangi hususlara dikkat edileceği, ne tür bilgilerin toplanacağ konusunda bir eğitim verilir ve formlar geliştirilir. Geliştirilen formları test için ilk iş olarak İçişleri Bakanlığı'nda çalışan Nuri Alpay çeşitli illere gönderir. Nuri Alpay'ın bu ilk temas ve tecrübeleri işlerin aksamadan yürümesi için alacakları tedbirler bakımından yararlı olur.

Yaklaşık iki yıl süren çalışmalar neticesinde yayınlanan "Coğrafya, tarih, ekonomi, ticaret, tarım, kültür, sosyal ve turistik bakımlardan Türkiye Kılavuzu” adlı eserin birinci cildinin hazırlayıcıları olarak şu isimlere ve görevlere yer verilmiştir: Müteşebbis ve sahibi: Hüseyin Orak, Düzenleyip Yazanlar: Öğretmen Mitat Artun, Öğretmen Mustafa Nihat Özön (1896 yılında İstanbul'da doğdu. İstanbul Darülfünunu Edebiyat Şubesi'ni bitirince (1923) öğretmenlik yapmaya başladı. Bu dönem, 1961'de Gazi Eğitim Enstitüsü edebiyat öğretmenliğinden emekli olana kadar, otuz sekiz yıl sürdü. Dergâh, Kalem ve Oluş dergilerinin yayımlanmasında etkin görev alan Özön'ün dil ve edebiyat alanlarındaki çalışmaları beş başlık altında toplanmaktadır. Edebiyat tarihçiliği, metin yayımları, sözlükçülük, çeviri çalışmaları, ders kitapları. Bu alanlardaki çalışmaları yaşamını kaybettiği 1980 yılına kadar yüz kadar kitapta toplanmıştır (http:// www.iletisim.com.tr/ki\%C5\%9Fi/mustafanihat\%C3\%B6z\%C3\%B6n565.aspx, Erişim: 25.02. 2012), Öğretmen Cevdet Alas, Öğretmen Reşat Özalp, Öğretmen Şaban Taşkın, Hüseyin Orak; Yurdu gezerek inceleme ve derlemeleri yapan: Nuri Alpay ve arkadaşları; Haritaları hazırlayanlar: Muhittin User ve Zeki Başaran, Ankara şehir planını hazırlayanlar: Hüseyin Orak, Mitat Artun, Desinatör Sabri Yetüman, Folklor kısımlarına yardım eden ve notaları veren: Ferruh Arsunar (dönemin önemli müzik ve folklor araştırmacısıdır. 1929 yılında Anadolu'ya gönderilen halk türküleri derleme heyetinde de yer almıştır. Türkülerin, oyun havalarının notaya alınmasında, bütün yurda yayılmasında Muzaffer Sarısözen ile birlikte çalışmışlardır. Köroğlu, Gaziantep Folkloru, En Güzel ve Seçme Şarkılar gibi önemli eserleri vardır. 21 Aralık 1965 yılında Ankara'da vefat etmiştir (http://www.turkuler.com/tgv/ferruh.asp, Erişim: 25.02.2012). Merkez bürosunda çalışanlar: Nuri Katırcıoğlu, Enver Ener, Feyzi Adsız, Basım ve teknik düzenlemeler: Necmettin Candan, Yılmaz Orak (oğlu), olarak belirtilmiştir (Orak, 1946, 2). Bu isimlerin dışında o günlerde Eskişehir Milletvekili olan Yavuz Abadan'da (1905-1967), Hukuk Fakültesi'ni bitirdikten sonra Heidelberg Üniversitesi'nde doktora yaptı. Yurda dönüşünde bitirdiği fakültede doçent oldu. 1942'de profesörlüğe yükseldi. 1943-1946 döneminde Eskişehir Milletvekili seçildi. Sonra Siyasal Bilgiler Okulu'nda görev aldı. Okul fakülteye dönüştürüldügünde dekanlığa getirildi (1952). Bu görevi sırasında Türkiye ve Ortadoğu Amme İdaresi Ensti- 
tüsü’nü kurdu, genel müdürlüğünü yaptı. 27 mayıs 1960 sonrasında 147'lerle birlikte görevinden alınan Abadan, bir süre Berlin Üniversitesi Hukuk Fakültesi'nde dersler verdi. Hakları geri verilince Hukuk Fakültesi'nde ve Eskişehir İktisadi ve Ticari İlimler Akademisi'nde görev aldı. Çalışmaları, üniversite çevrelerinde "kamu hukuku ve siyasal bilime yapılmış önemli katkılar" olarak değerlendirildi. Başlıca yapıtları: Hukuk Başlangıç ve Tarihi (1935), Hukukun Gözü ile Milliyetçilik ve Halkçılık (1938), Türkiye'de Anayasa Gelişmelerine Bir Bakış (B. Savcı ile birlikte, 1959), Mustafa Kemal ve Çetecilik (1964), (http://www.kenthaber.com/ icanadolu/eskisehir /Kimdir/izbirakan/yavuzabadan, Erişim: 25.02.2012) çalışmalara fiilen iştirak etmiştir (A. Sahavet Özbay ile yapılan görüşme, 24 Haziran 2011).

Çalışma esnasında yerinde tetkik ve bilgi toplama yollarının dişında şu eserlerden faydalanıldığ kaydedilmektedir: Hayat, İslam, Meşhur Adamlar ve İstanbul Ansiklopedisi, Küçük Asya, Evliya Çelebi Seyahatnamesi, La Turquie D’asie, Türkiye Coğrafyası (Faik Sabri Duran), İktisadi Türkiye (Hamit Sadi Selen), İktisadi ve İçtimai Türkiye, Türkiye Havzaları ve Anayolları, Milli iktisat ve Tasarruf Cemiyeti Yayınları, Büyük Türkiye, Balneoloji (Sözcük anlamı banyo bilimi olan balneoloji, yer altı, toprak, su ve iklim kaynaklı doğal terapötik faktörlerin bilimi olarak tanımlanabilir. Doğal şifalı sular, çamurlar ve iklimsel faktörler gibi doğal terapötik kaynakları fiziksel, kimyasal, biyolojik, jeolojik, hidrolojik, ekolojik ve medikal yönden inceler. Bu nedenle fizik, kimya, biyoloji, hidroloji, jeoloji, klimatololoji ve tıp gibi değişik bilim dallarını bünyesinde toplayan interdisipliner bir alandır. (http://zehirlenme.blogspot.com/ 2010/10/ balneoloji-ve-balneoterapi-nedir.html, Erişim: 24.02.2012). (Dr. Rıza Reman), Orta Yaylalar, Stradağlar, Madenlerimiz, Güneydoğu, Asar ve Mahkukat, Kültür, Ziraat ve Ticaret Istatistikleri, İstatistik Yılliğl, DDY Nakliyat İstatistikleri, Köylerimiz ve Nüfus İstatistiği, Genel Nüfus, Hayvanlar, Meyveler ve Zeytincilik Istatistikleri, Anadolu Beylikleri, Ülkü, MTA (Maden Tetkik Arama), Iktisadi Yürüyüş, Belediyeler ve Vilayetler Dergileri koleksiyonlarl, Turizm Kılavuzu, Halk Şairleri Antolojisi, Türk Dügü̈nleri, İdari Taksimat, Bursa'dan Konya'ya Seyahat gibi önemli eserlerden ve Türkiye'nin muhtelif mikyasta haritalarından (Kaynaklar Hüseyin Orak'ın belirttiği biçimde nakledilmiştir) (Orak, 1946, 18).

Eserde halkın kullandığı dilin kullanıldığı vurgulanarak, yeni terimler ve eski tabirlerin de bu esasa göre alındığı kaydedilmiştir. İhsai malumat (sayıma ait bilgiler) hiçbir ekleme ve çıkarmaya tabi tutulmaksızın resmi kaynaklardan olduğu gibi aktarılmış, 1945 sayımı verileri ilk cildin yayımı esnasında yayınlanmamış olduğu için burada 1940 yılı sayımı verileri dikkate alınmıştır.

Türkiye Kılavuzu çalışmasının dikkat çeken bölümlerinden birisi de her il ve ilçede doktor, avukat, ebe, dişhekimi, tüccar, işadamlarının isim isim verilmesidir. Bununla kılavuzun yıllarca ihtiyaca cevap vermesi hedeflenmiş, hatta bu isimler belirlenirken o il veya ilçede ikamet edip etmediklerine bakılmıştır. Kitapta, bu ismi geçenlerden hiçbir şekilde hiçbir ücret alınmadığının da altı çizilmiştir.

İdari taksimat bakımından il, ilçe ve bucaklara kadar inilmekle birlikte köyler sayısal olarak ifade edilmiştir. Birinci ciltte Afyonkarahisar, Ağrı, Amasya, Ankara, Antalya, Aydın, Balıkesir, Bilecik, Bingöl, Bolu, Burdur, Bursa, Çankırı olmak üzere 14 il ele alınmış, bunların ilçelerine de büyüklüklerine göre değinilmiştir.

Her ille ilgili bölümün başında çalışmanın nasıl gerçekleştirildiği açıklanmış, ille ilgili saha çalışmalarını kimlerin yürüttüğü, bu kişilerin gittikleri yerlerde kimlerle görüştükleri, ayrıca ille ilgili bölüm yazılırken sahada elde edilen bilgiler dışında hangi kaynaklardan yararlanıldığı belirtilmiştir (Orak, 1946, 25).

İllerle ilgili genel olarak şu başlıklar altında bilgiler verilmiştir:

İl nasıl yazıldı? İl ve ilçelere nasıl gidilir? İlin coğrafi durumu: Arazi durumu, iklimi, suları, 
ziraat ve bitki durumu, hayvancılığ ziraat ve flora, hayvancıllk, maden yatakları, ticareti, yolları, taşıtları, nüfusu ve idari bölümü; İlin coğrafi konumu ve tarihi: Abideleri ve eski eserleri, nüfusu, ticareti, tüccar ve işadamları, taşıtları, otelleri, lokantaları ve berberleri, kıraathaneleri ve hamamları, kültürel ve sosyo kültürel durumu, doktor ebe ve avukatları, folkloru, yetiştirdiği büyük şahsiyetler ve milletvekilleri, sağlık hizmetleri, içme suları, şifalı suları, aydınlatma durumu, muhabere vasıtaları, eğlence ve mesire yerleri; İlçeleri...

Fotoğraflar ve haritalar gibi malzemelerle bezenmiş "Türkiye Klavuzu" gibi bir eserin, Cumhuriyet Dönemi'nde devlet eliyle ulus inşa etme sürecinde önemli bir işleve sahip olduğu söylenebilir. Yayımlandığı zaman, Milli Eğitim Bakanı'ndan Cumhurbaşkanı'na kadar birçok devlet adamından ve aydından aldığı övgüye değer takdiri de bu açıdan değerlendirmek mümkündür. Anderson'a göre, modernleşme sürecinde matbaa sayesinde yazılı iletişim imkanlarının artmasıyla oluşan yazılı kültür ortamında şekillenen kamuoyu ile bir devletin egemenlik temelini oluşturan halk topluluğunu "millet" olarak hayal etmek mümkün olmuştur. Uluslaşma sürecinde nüfus sayım1, harita ve müze olgusunu vurgulayan Anderson, bunun devletin mülkünü, bu mülkün coğrafyasını, yönetilen insanların doğasını ve eskiliğinin meşruluğunu nasıl hayal ettiğini derinden belirlediğini ifade eder (Anderson, 1995, 182). Türkiye Kılavuzu isimli eser incelendiğinde; Anderson tarafından vurgulanan her üç husus ile birlikte il il birçok konuda değerli bilgiler aktarıldığ görülür. Kısacası, modern toplum yaşamı, giderek artan bir iletişim ihtiyacını, bütün yurttaşlarını belirli standartlar çerçevesinde eğitme gereğini ortaya çıkarır. Böylece modern toplumlar, bir yandan bütün halkın ortak iletişim aracı olan dilin standardını belirlerken, diğer yandan bu ve diğer standartları bütün topluma yaymanın araçları olarak eğitim gibi kurumları yaratmaya çalışır (Belge, 2011, 110-112).

Birinci cildi toplam 850 sayfa olarak basılan eser, 1750 kuruş fiyatla okuyucuya sunulur. Hüseyin Orak'ın kızı Sahavet Hanım'a imzaladığı nüshada belirttiği gibi, çocuklarının yurt seyahati ile başlaşan bir süreç nihayete ermiştir: "Kızım Sahavet, hayatımın ellinci yılında yazdl$\breve{g ı m ~ a z i z ~ y u r d u m u n ~ b u ~ r e h b e r i n i ~ s i z d e n ~ a l d ı g ̆ ı m ~ i l h a m l a ~ h a z ı r l a d ı m . ~ B u ~ b e n i m ~ s i z e ~ b ı r a k a c a ̆ ̆ ı m ~}$ mirasın en büyüğ̈̈dür. Çünkü onun içinde tüm dünyaya bedel Türk vatanı vardır. Beni hatırladikça bu eşsiz eserin içinde daima arar, bulur ve görürsün. Gözlerinden şefkatle öper, hayat yolculuğunun çetin yollarında mesut olmanı Ulu Tanrı'dan dilerim. 27.03.1946". Burada, 19. yüzyılın ortalarından itibaren Osmanlı İmparatorluğu'nda gelişmeye başlayan; "atalardan miras kalmış topraklar", "kendileri için kan dökülmüşs topraklar" gibi deyişler temellinde şekillenen bir “vatan fikri”nin Orak'ın düşüncesinde önemli bir yer işgal ettiğini anlıyoruz. 1860-1870 yıllarında büyük Osmanlı şairi Namık Kemal tarafından güçlü bir şekilde dile getirilen vatan fikri, Jön Türk kuşağını da besleyerek 20. yüzyılın başında imparatorluğun yönetici sınıfı ve seçkinlerinde "devlet vatanseverliği" ve "Türk milliyetçiliği" șeklinde billurlaşan temel iki kavrama ve ideolojik akıma hayat verdi (Georgeon, 2006, 16-17). Devleti, vatanı korumak ve gerektiğinde kurtarmak duygusu ve düşüncesi, Osmanlı seçkinleri kadar cumhuriyet seçkinlerinde de oldukça baskın bir duygu ve düşüncedir. Resmi ideoloji, toplumun üyelerinin milli birlik içinde, ülke bütünlüğünü ve bölünmezliğini savunmasını ve bu yönde davranmasını ister (Ünsal, 1998, 20). Cumhuriyetin kurucu kadrosunu ve yetişmekte olan kuşağı derinden etkileyen böyle bir duygu ve düşüncenin güçlü etkilerini, bizzat Orak'ın şahsında da müşahede ediyoruz.

Kitap çıktığı andan itibaren özellikle ülke yönetiminde bulunanlardan ve üniversite, milli eğitim çevrelerinden, medyadan çok olumlu tepkiler almıştır. Cumhurbaşkanı (Milli Şef) İsmet İnönü, çalışmaya ilişkin Hüseyin Orak’a gönderdiği kutlama mesajında: "Türkiye Kılavuzu, sebatl çalı̧̧manın kıymetli bir mahsulüdür. Cemiyetimizin her katı için faydalı ve her kitaplığlmızın başlıca eserlerinden biri olacaktır" (Türkiye Klavuzu Hakkında Broşür 1, 1946) demiştir.

Çalışmanın en başından beri takip eden Maarif Vekili Hasan Âli Yücel de bir yazı ile 
kamuoyuna kitabın önemini anlatmak ister ve şu cümleleri yazar: "Memleketimizi içte ve dışta tanıtacak eserlere ihtiyacımız büyüktür. Yurdumuzun tabiat güzelliklerini, tarih yadigârlarını, ürünlerini, ekonomik ve kültürel durumunu aydınlatan ve her meslekten insanı ilgilendirecek olan böyle bir kllavuzu çok bekledik. Hüseyin Orak'in teşebbüsü ile vücuda gelen Türkiye Kılavuzu, bu ihtiyacımızı karşılamakta ve bekleyişimizin boşa olmadığını göstermektedir. Türkiye Kllavuzu ticaretle uğraşan ve yaşama konusu tabii olarak kâr ve menfaat olan bir yurttaşın kazançlarını memleket sevgisi ile memleket yoluna vermesinin çok klymetli bir örneğidir. "Herşey gibi para da memleket içindir" düşüncesinin bir hayal olmadığına Hüseyin Orak unutulmayacak bir misal vermiştir. Büyük emekle hazırlanmış bu eserin meziyetleri ve faydaları, kolayca tashih edilebilecek kusurlarını karşılayacak değerdedir. Fertçe ve devletçe bu hayırl, hatta cüretli teşebbüsü desteklemenin bir vazife olduğu kanaatindeyim. Müteşebbisini ve çalışma arkadaşlarını takdirle karşılarım. Memleket irfanı adına kendilerine bütün yüreğimle teşekkür ederim (19 Mart 1946)." (Türkiye Kılavuzu Hakkında Broşür 1, 1946). Kitapla ilgili olarak, TBMM Başkanı M. Abdülhalık Renda, CHP Genel Sekreteri N. Kansu, Dışişleri Bakanı Hasan Saka, Eskişehir Milletvekili Yavuz Abadan gibi siyaset adamlarının yanı sıra Enver Ziya Karal, Faik Reşit Unat, Ali Fuat Başgil, İ. Alaaddin Gövsa gibi kamuoyunca bilinen bilim adamı ve yazarlar da övgü dolu ifadeler kullanırlar (Türkiye Klavuzu Hakkında Broşür 1, 1946). Ulus Gazetesi, "Çok Faydalı Bir Eser" başlıklı uzun bir değerlendirme yazısı yayınlayarak, Kılavuz'un neden yayınlandığını ve hangi amaçlara hizmet edeceğini aktarmıştır (Ulus 20 Mart 1946). Son Telgraf Gazetesi'nde Reşad Feyzi Yüzüncü, eseri okuyucularına eseri anlatırken şu cümleleri kurmaktadır: “... Ağrl vilayetine dair bu memlekette kaç kişi ne bilir? Türkiye Kılavuzu adlı eserde, A $\breve{g r l}$ vilayetindeki halk türküsüne, bu türkünün şivesine, notasina kadar her şeyi bulabilirsiniz. Yolunuz Ağrı'ya mı düşü, hangi otelde kalacaksınız? Otellerin sayısına ve ismine kadar bu cilt içinde mevcuttur. Esere ilave edilmiş harita ve krokiler harikadir. ..." (Son Telgraf 27 Mart 1946). Türk Dili Gazetesi'nde Vehbi Evinç “Mühim Bir Eser" başlıklı yazısında eser üzenine övücü cümleler kurarken, her Türk aydınının ve tüccarının bu eseri almasını önerir (Türk Dili Gazetesi 28 Mart 1946). Ankara Gazetesi'nde "Başkentin Kılavuzu" başlıklı makalede, Ankara bölümüne dikkat çekilerek çalışma takdirle karşılanmıştır (Ankara Gazetesi 30 Mart 1946). Aydın Gazetesi'nde de "Türkiye Kılavuzu" başlıklı yazıyla eserin önemi üzerine uzun uzun durulmuş; "Gezmek görmek muhakkak ki okumak yazmak kadar faydalı bir iştir. Evvelce seyahatin zevki meşakındadır (meşakkat: sıkıntı) diyorlardı, bugün gezinin sırrı kılavuzdadır, diyorlar" cümlesiyle esere dikkat çekilmektedir (Aydın Gazetesi, 30 Haziran, 1946). Esere zamanın önemli yazarlarının ilgisini köşelerindeki övücü yazılardan takip mümkündür. Akşam Gazetesi'nde Va-Nu (Akşam Gazetesi, 31 Mart1946), Son Posta'da İsmet Hulusi İmset (Son Posta, 31 Mart1946), Burhan Cahit (Son Posta, 03 Nisan1946), Mithat Cemal Kuntay (Son Posta, 03 Mart 1946), Pazar Gazetesi'nde Aygün (Pazar Gazetesi, 1 Nisan 1946), Cumhuriyet'te Abidin Daver (Cumhuriyet, 2 Nisan 1946), Yeniçăg Mecmuası'nda Orhan Seyfi Orhon (Yeniçağ Mecmuas1, 06 Nisan 1946), Türk Yolu Gazetesi'nde Cevdet Baykal (Türk Yolu Gazetesi, 12 Nisan 1946), Ülkü Dergisi'nde Ali Gündüz (Ülkü Dergisi, 16 Nisan 1946) bu eserin önemi üzerine çok takdir edici yazılar kaleme almışlardır. Ancak Vakit Gazetesi’nde Hakkı Süha Gezgin'in kitaba ve hazırlayıcısına övgüsü çok dikkat çekicidir. Gezgin, daha önce hiç bilmediği, tanımadığı bu garip işadamının çalışmasını "Gayret Himalayası" olarak niteler (Vakit Gazetesi, 30 Nisan 1946).

Her kesimden olumlu, övgü ve takdir dolu desteğe rağmen Türkiye Kılavuzu'nun birinci cildi halkta ilgi görmez. Hüseyin Orak için maddi sıkıntılar bu aşamadan sonra aşılmaz olur. İşyerleri, fabrikaları, evi ipoteklidir. Kitaptan dolayı büyük bir borç yükü altına girmiştir. Resmi kurumlar satın alınması için genelgeler yayınlamalarına rağmen kendileri tahsisatları olmadığı gerekçesiyle kitaptan doğrudan alıma gitmemişler; 1750 kuruşluk fiyat da o günün şartlarında halk tarafından çok bulunmuştur. 
İşe bir vatan borcu olarak başlayan, ciddi bir sosyal sorumluluk anlayışı içinde hareket eden, karşılığında büyük bir eser oluşturan Hüseyin Orak, borçlarının altından kalkamaz hale gelir. Kamuoyunun bu derin ilgisizliğine karşı tepkisini elindeki tüm kitapları ve yayınlanacak ciltlerin dokümanlarını, taslaklarını sahibi olduğu Ankara Dikmen Keklikpınarı'ndaki kireç ocaklarında yakarak gösterir (Ayșe Sahavet Özbay ile yapılan görüşme, 24 Haziran 2011, Ankara). Evini satar, işyerlerini satar, tasfiye eder, kadim dostlarının da kısmi yardımlarıyla hayatını sürdürmeye uğraşır. Ancak iş hayatından kaynaklanan sorunları ailevi durumuna da etki eder. Eşinden ayrılır, sonraki yıllarda yeniden ticari hayatını canlandırmaya uğraşır, çok başarılı olamaz. Hayata asker olarak başlamış olmak, değişik dönemlerde askeri vazifeler ifa etmek ilerleyen yaşında işe yarar, kendisine Milli Savunma Bakanlığı'nca bir miktar gazi emekli-malül aylığı bağlanır. Büyüyüp iş güç sahibi olan çocuklarının da katkılarıyla yaşamını sürdürür ve 1968 yılında vefat ettiğinde askeri törenle, Ankara Cebeci Askeri Şehitliği’nde toprağa verilir (Ayşe Sahavet Özbay ile yapılan görüşme 24 Haziran 2011, Ankara).

\section{2) Türkiye Kılavuzu İçinde Antalya İli}

Türkiye Kılavuzu'nun 321. sayfasından 372. sayfasına kadar olan bölümü Antalya iline ayrılmıştır. Bölümün nasıl yazıldığının anlatıldığı kısımda, yukarıda zikredilen kaynakların dışında, ayrıca Halkevi yayınlarından çıkan Cumhuriyet'in XV. yllında Antalya, Bizim Akdeniz, Antalya İkinci Dünya Harbi’nde Nasıl Güzelleştirildi adındaki eserlerden faydalanıldığı, ayrıca; A.Ü. DTCF Asistanlarından Ali Gündüz ve MEB Yayın Şube Müdürlügü’nden Şahap Sitkı'nın bölgeye gönderildiği, mahallinde tetkik ve derlemelerde bulundukları, buna ek olarak Vali Haşim İşcan, Maraş Milletvekili (Antalya-Aksekili) Rasih Kaplan, DDY Hasılat Dairesi'nden Mihmit Temoçin, tüccardan Hasan Göksoy, Ahmet Irız, Müze Müdürü Süleyman Fikri Erten, Antalya Gazetesi sahibi Mazlum Adıson, Ticaret Odası Başkatibi Macit Selekler, Lise Coğrafya Öğretmeni Hüseyin Saraçoğlu, Elmalı Belediye Başkanı Ramiz Çoşkun, Öğretmen Hayri Artukoğlu, Abdullah Demirel, Manavgat Hükümet Hekimi Dr. Asım Okur, Parti Başkanı (CHP) Hüseyin Öz, Korkuteli Milli Eğitim Memuru Turgut Özbek, Alanya Halkevi Başkanı Emin Cengiz, öğretmen Mustafa Kelleci, Kaş Dava Vekillerinden Avni Erdem ile görüşüldügü ve onların bilgi ve yardımlarının alındığı kaydedilmektedir (Orak, 1946, 323).

O günün koşullarında Antalya İline nasıl gidildiği de belirtilmektedir: Antalya'ya Akdeniz'e işleyen vapurlarla her taraftan gidildiği gibi İstanbul ve Ankara'dan Afyon Treni ile Burdur'a, İzmir'den Aydın hattı ile Dinar'a oradan Burdur'a, Konya cihetinden trenle Afyon'a ve buradan Burdur'a, Burdur'dan da otomobille her zaman ve her mevsimde Antalya'ya gidilebilir (Orak, 1946, 323). Antalya ili özelinde karayolu ve demiryolu ağındaki gelişmeyi, Osmanlı' dan başlayarak Cumhuriyet Dönemi'nde de sürdürülen modernleşme ve kalkınma hamleleri çerçevesindeki ulaşım politikalarının bir parçası olarak görmek gerekir. Özellikle 1850'den sonra, demiryollarının yapılması ve bir karayolu ağının oluşturulması, ulaşım ve iletişim imkanlarını artırarak Osmanlı toplumunda yaşanmakta olan değişime yeni bir boyut ve hız katmıştır. Bu sayede yalnızca kıyı kesimlerinde değil, aynı zamanda iç bölgelerde de kentleşme oranları yükselmeye başlamıştır. Başlangıçta tarım sektöründe başlayan değişim, zamanla diğer sektörlere de yayılmıştır (Karpat, 2006, 455).

Çalışmada Antalya'nın coğrafi durumu, arazi durumu, iklimi, suları, hayvancılığı, yeraltı zenginlikleri ve madenleri, sanayi üzerinde durulmaktadır. Özellikle sanayi ile ilgili olarak, kereste ve ambalaj sandığ 1 imalathaneleri, araba ve mobilya tamir ve imalathaneleri, merkezde iki dökümhane, demircilik, kunduracılık, kahve değirmeni yapımı, kavaflık vs. gibi ufak sanatlarla, Alanya'da 100-120 tona kadar motorlu gemiler ve yelkenli kayık yapan Selçuk tersanesi olduğu, sandık imalathanelerinin ise en çok merkez ve Alanya' da bulunduğu bilgisi verilmektedir. İlde dokumacılığın kayda değer bir durumda olduğu belirtilerek; bilhassa Alanya, Akseki, Korkuteli, Gündoğmuş ve merkez ilçelerinde kooperatifler vasıtasıyla teşkilatlanmış, gelişmiş olduğu 
kaydedilir. İlde un ve çeltik fabrikalarıyla en çok tahin imalathaneleri olduğu, merkezde iki un, iki çeltik fabrikası, 6 tahin imalathanesi, Kaş'da bir un, Fenike'de bir çeltik, bir un, Manavgat'ta 10 tahin imalathanesi olduğu zikredilirken, ilde modern bir hayvancılık sanayinin bulunmadığ iptidai şekilde başka Akseki olmak üzere Antalya, Elmalı ve Gündoğmuş'da tabakçılık (deri işçiliği) olduğu ifade edilmektedir. Akseki'de yapılan kösele, deri vb. imalatın ancak mahalli ihtiyaca cevap verebilecek düzeyde olduğu, yine hayvan mamullerinden kıl, yün; yayla bölgelerinde ise, özellikle Serik, Manavgat'da beyaz ve tulum peyniri, bir miktar da yağ üretimi bulunduğu belirtilmektedir. Maden sanayine dair verilen bilgilerde Tekirova Krom maden ocaklarından 6 yıldan beri yapılan üretimin yurtdışına ihraç edildiği vurgulanmaktadır.

Antalya'nın ticari hayatı ile ilgili aktarılan bilgilerde; portakal, limon, mandalina gibi turunçgiller ile hububat, pirinç, susam, tahin, zeytin, muz, turfanda meyve sebze, malta eriği, kurutulmuş meyve, ceviz, badem, kayısı çekirdeği, Amerikan fistığı, ambalaj sandığı, kereste, odun, kömür, çam kabuğu, palamut, kitre, keçi boynuzu, reçine, mazı, çöven, tavuk, yumurta, balık, kavun, karpuz, at, kasaplık hayvan (bilhassa keçi), kıl, yün, krom, ham deri, av derisi, bir miktar da peynir ve yağ, ipek kozası, bal ve balmumu, pamuk, havyar ve sünger gibi malların ticareti üzerinde döndüğü belirtilerek; Antalya limanının civar il ve ilçelerle önemli bir transit merkezi olduğu, Burdur, Isparta çevresinin bir kısım ihraç ve ithal mallarının Antalya'dan gelip geçtiği, bu nedenle şehrin Akdeniz'in bir hayli işlek bir ticaret merkezi olduğu vurgulanır.

Yurtiçi ticaret ürünleri olarak, turunçgiller, turfanda meyve, sebze, tahin, pirinç, kasaplık hayvan, ham deri, kereste, k1l, yün, yerli dokuma, muz, zeytin, bir miktar koza, bal ve balmumu, peynir, ceviz, badem, ıhlamur çiçeği, yurtdışı ihracat ürünleri olarak ise, kereste, odun, kömür, kasaplık hayvan, maden, turunçgiller, kı1, yün, Amerikan fistı̆̆ı, tahan, palamut, çam kabuğu, pirinç, mazı, reçine, balık ve havyar sayılmaktadır (Orak, 1946, 323-324). Yurtdışı ihracat ise genellikle Suriye, Misır ve adalara yöneliktir.

Yukarıda Antalya'ya ilişkin olarak aktarılan bilgiler, hiçbir uygarlıkta kent yaşamının, ticaret ve sanayiden bağımsız olarak gelişemediği tezini bir kez daha teyit etmektedir. Ne Antik çağda ne de modern zamanlarda bu kuralın dışında kalan bir örnek bulunmadığını ileri süren Pirenne'ye göre, "Bu evrensellik, zorunlulukla açıklanmaktadır. Gerçekten, bir kent grubu, ancak yiyecek maddelerini dışarıdan getirterek yaşayabilir. Ancak, bu dış alımın, buna denk düşen ya da bununla eşdeğerdeki mamul ürünlerin dışsatımıyla dengelenmesi zorunludur. Böylece, kentle çevresindeki kırsal bölge arasında sıkı bir karşıllıkl hizmet ilişkisi kurulur. Bu karşıllıkl bağımlılığın sürdürülebilmesi için ticaret ve sanayi vazgeçilmez öğelerdir; sürekli bir alışverişs sağlamak için birincisi, değişim amacıyla mal sağlamak için de ikincisi olmasayd, kent yok olup giderdi" (Pirenne, 1994, 103-104).

Hiç kuşkusuz, bütün dünyada şehirler, içinde yer aldıkları toplumların özelliklerini yansıtırlar. Başka deyişle, toplumsal sistemi oluşturan diğer öğelerle ve bizzat toplumsal bütünün kendisiyle ilişki ve etkileşim içinde olan şehirlerin, tamamen kedilerine özgü karakteristikler göstermeleri beklenemez. Bu bağlamda Antalya'ya bakıldığında; yurt içi ve yurt dışı ticarete sunduğu ürünlerin türleri, bunların üretim ve imalat süreçleri bakımından ne tümüyle modern öncesi veya geleneksel toplum yapısına ne de modern toplum yapısına has bir görünümde olmadığı görülür.

Geleneksel toplumlarda şehirler, genel olarak pazar ve mübadele merkezleridir. Küçük zanaat ve esnaf işletmeleri ağırlıklı bir yere sahiptir. İmalat sürecinde başta insan gücü olmak üzere kas gücünün sağladığı enerji başat bir konumdadır. Ekonomik hayatta iş bölümü ve uzmanlaşma sınırlıdır. Sosyal hareketlilik ve sosyal tabakalaşma bakımından da benzer bir manzara söz konusudur. Modern sanayi toplumlarında ise, şehirler hem sanayi ve ticaret merkezi özelliğine, hem de idari ve mali birçok işleve sahiptir. Buhar, motor ve elektrik enerjisi gibi organik temelli olmayan enerji kaynakları tarım ve sanayi üretim sürecinde; ulaşım ve haberleşmenin sağlanmasında çok önemli bir yere sahiptir. Toplumsal farklılaşma, tabakalaşma, 
işbölümü ve uzmanlaşma daha ileri bir aşamadadır (Kıray, 1982, 265-266). Antalya'nın, 1940'lı yıllarda nispeten kendi içinde farklılaşmış ve ihtisaslaşmış iş düzeni ve ekonomik yaşamıyla, özellikle tarımsal ürünlere ve doğal zenginliklere dayalı ticaret hayatıyla modernleşme sürecini yaşamakta olan bir geçiş toplumunun temel karakteristiklerini göstermekte olduğu söylenebilir.

Antalya'nın "yolları" ile ilgili kısımda önce denizyolu anlatılmaktadır: Antalya İzmir'e denizden 390 ve Mersin'e 220 mil mesafededir. Şoseleri başlığı ile, karayolu ulaşımı üzerinde durulmaktadır: Antalya- Korkuteli 68, Korkuteli-Elmalı 52, Elmalı- Finike arasında 118 km.lik oldukça iyi bir şose vardır. Kaş- Elmalı arasında 114. km tamire muhtaç bir şose vardır. Antalya-Manavgat arasında $89 \mathrm{~km}$.lik araba yolu ile, Manavgat-Gündoğmuş arasında $70 \mathrm{~km}$.lik bir hayvan yolu mevcut olup, bu yolların ikisi de yapılmakta, Antalya ile bu ilçelerin muvassalası (ulaşımı) Manavgat üzerinden temin edilmektedir.

Diğer yollarla ilgili de ayrıntılı olarak bilgi verilmektedir. Görülen o ki, ilin ilçeleriyle ve köyleriyle ulaşımı bir hayli sorunludur. Antalya'dan diğer illere ulaşımla ilgili de yollar bakımsız, yer yer tesviye edilmiş, araba yolları olarak anlatılmaktadır. Yalnızca Antalya-Burdur yolu arasındaki $120 \mathrm{~km}$.lik yol "muntazam şose" olarak değerlendirilmektedir.

Antalya'nın İstanbul, İzmir ve Mersin'e denizden muntazam işleyen posta vapurları ile bağlı olduğu gibi, sahil ilçeleri arasında yelkenli ve motorlu deniz taşıtları ve Antalya-Burdur arasında daima işleyen otomobil, kamyon ile, diğer ilçeler arasında çalışan kamyon, araba, hayvan gibi nakil vasıtaları bulunduğu belirtilmektedir. Ulaşım imkanları açısından, toplumsal değişim sürecinde Antalya'ya bakıldığında; bir kentin sosyo-kültürel bakımdan dönüşümünde ulaşım ağının ve özellikle liman kenti olmasının önemli bir rol oynadığını kaydetmek gereklidir. Osmanlı İmparatorluğu, 18. ve 19. yüzyılların değişim ve dönüşümlerinden geçerken Osmanlı ekonomisi ve piyasaları esas olarak liman kentlerinden iç kesimlere doğru kollara ayrılan yol ağlarıyla Avrupa piyasalarına bağlanarak onların etkisi altına girdi (Kasaba, 1998, 16). Bu dönemde Osmanlı İmparatorluğu'nun Batı ya da Avrupa merkezli modernleşme projesine çevreselleşerek eklemlenmesi, Osmanlı ekonomik ve toplumsal yapısında yol açtığ paralel olarak kentlerde de bir değişim yaratıyordu. Özellikle önemli liman kentlerinde değişen ticaret biçimi ve kentlerin değişen dış bağlantıları, şehirlerde geleneksel merkez dışında yeni bir modern merkezin doğmasına neden oluyordu. Şehir içi ilişkilerin yaya olarak kurulması terk ediliyor, bağlantıları bundan böyle araba ve tramvay gibi toplu taşıma araçları sağlıyordu. Bu da şehir nüfusundaki artışlara bağlı olarak yeni alanların iskana açılması anlamına geliyordu. (Tekeli, 1998, 142-146).

XIX. yüzyılın özellikle ikinci yarısında şehirlerde önemli gelişmelerin ortaya çıktığını ve bu arada şehirlerin kırsal kesime oranının artmaya başladığını belirten Karpat'a (2002, 143-147) göre, bu dönemde ekonomi, özünde tarıma dayalı olup büyük bir kısmıyla geçimlik nitelikteydi. Tarımın uzmanlaşmış ve ihracata yönelik sektörleri, limanlara kolay ulaşıma sahip küçük şehirlerin çevresinde toplanmıştı. Bundan dolayı da şehirlerin gelişmesi, taşımacılık ve depolama gibi hizmetler kapsamında iş imkanı sağlayabilen liman şehirlerinde ve bunlarla bağlantılı küçük şehirlerde mümkün olabildi. Başka bir deyişle, dış ticaretin liman şehirlerini tarımsal ürünlerin Avrupa'ya ihraç kapısı haline getirmesiyle, şehirleşme esas olarak kıyı bölgelerinde gerçekleşti.

Osmanlı İmparatorluğu'ndan Türkiye Cumhuriyeti'ne geçişle birlikte, Türkiye'nin modernleşme projesinde ve bu çerçevede mekansal örgütlenmesinde önemli değişmeler meydana gelmiştir (Tekeli, 1998, 142-146). Türkiye'nin Cumhuriyet sonrası kentleşme deneyiminin 19231950 y1lları kapsayan dönemini "Ulus-Devletin kentleşmesi” olarak niteleyen Şengül'e göre, ulus-devletin oluşumunun ön koşulu olan "ulusal birlik" ve "kimliğin" yaratılması, böylesi bir yapının kurumsal düzeyde de örgütlenmesini gerektiriyordu. Söz konusu ulus-devlet oluşturma stratejisinin izlerini, Ankara'nın başkent yapılmasında, kamu iktisadi teşebbüslerinin yurt sathına yaygınlaştırılmasında ve Anadolu'ya görece önem veren ulaşım ağının oluşturulmasında gör- 
mek mümkündür (Şengül, 2012, 362-365). Cumhuriyet Dönemi'nde Antalya'nın deniz yolu yanında özellikle karayolu ve demiryolu temelli bir ulaşım ağı ile merkeze ve ülkenin diğer yörelerine bağlanması yönündeki çabaları bu açıdan da değerlendirmek gerekir.

“Nüfusu ve İdari Bölümü" başlığı altında, 1940 yılı Nüfus Sayımı verilerine göre Antalya'nın nüfusunun 256.366 olduğu, bunun 123.397'sinin erkek, 132.969'unun kadın olduğu, toplam nüfusun 50.101'inin merkez ilçede yaşadığ kaydedilmektedir. Keza ilin merkez ilçe dahil 10 ilçesi (Merkez, Akseki, Alanya, Elmalı, Finike, Gündoğmuş, Kaş, Korkuteli, Manavgat, Serik). 21 bucağı, 587 köyü olduğu bilgisi verilmektedir. Kentleşme oranı ve kent-kır ayrımı bakımından şüphesiz nüfus faktörü önemli bir değişkendir. Nüfus, sadece toplumun devamını mümkün kılan bir biyolojik öge olarak değil; aynı zamanda iş-güç biçimlerini, dünya görüşünü, yaşam biçimini, dayanışma ve örgütlenme tarzını etkileyen bir faktördür. Antalya'nın 1940'lı yıllarındaki nüfusu ketleşme açısından değerlendirildiğinde; 50.000'ni geçen merkez nüfusuyla; nüfusun tarım, sanayi ve hizmet sektörleri arasındaki dağılımıyla; kent nufusunu oluşturan bireylerin tutum ve davranışlarındaki değişikliklerle nispeten giderek gelişen bir şehir manzarası sunduğu sonucuna ulaşılabilir.

Çalışmada şehrin tarihi üzerinde de durulmaktadır. Keza eski eserleri ve abideleri üzerinde fotoğraflarla zenginleştirilmiş ve tarihi dönemlere göre tasnif edilmiş bilgi aktarılmaktadır.

O yılların Antalya'sı için mühim işadamları ve tüccarların isim ve iş alanları da çalışmada yer almaktadır. Sayılan isimlerin iştigal alanları çoğunlukla sandık imalatı, kereste, tahin, hububat, sabun imalat ve ticareti olarak belirtilmektedir (Orak, 1946, 340-341).

Önemli lokantalar olarak, Akdeniz Lokantası, Cumhuriyet ve Şehir Kulübü lokantaları, sonra Lezzet ve Safa lokantaları sayılır. Bunların dışında çarşı içinde 20 kadar köfteci ve börekçi olduğu belirtilir. "Berberleri" başlığ 1 altında verilen kısımda ise Hükümet Caddesi'nde Hasan Çavuş Berber Salonu ile Hüsnü Altan Traş Salonu'nun iyi durumda olduğu, bunların haricinde 10 'dan fazla berberin bulunduğu bilgisi vardır. Şehrin kıraathaneleri, gazinoları, hamamları da ihmal edilmemiştir. Bunlar hakkında da bilgiler bulunmaktadır. Yenikapı'daki Bilardolu Kıraathane, Hükümet Caddesi'nde Borsa Kıraathanesi, Şehir Kulübü, denize nazır Park ve Tophane gazinoları kayda değer bulunarak ayrıca şehirde dört hamam bulunduğu ifade edilmektedir.

"Kültürü ve Sosyal Durumu" başlığı altında, şehirde orta kısmı ve 200 kişilik pansiyonu bulunan bir lise, bir kız enstitüsü, aynı bina dahilinde bir akşam kız sanat okulu, bir biçki ve dikiş kursu, 8 ilkokul ile Aksu Köy Enstitüsü ve 8 öğretmenli ve 21 eğitmenli bir okul bulunduğu, daha pek çok ilkokulun inşasının devam ettiği bunun dışında halkın eğitim seviyesini yükseltmek için Ulus okullarının da faaliyette olduğu bilgisi verilmektedir. Muzlum Alison'a ait Antalya Basımevi, Sadri Tunca Basımevi, Antalya adıyla haftada bir yayınlanan bir yerel gazete, Tarih ve Etnoğrafya Müzesi, 4000 kitaplı Halk okuma odası, 300 kitaplı lise kütüphanesi, 2000 kitaplı Öğretmenler Kütüphanesi, $M E B$ yayınlarını satan Dilek Kitapevi, Tan Kitabevi, Turan Kitabevi, Ahmet Cevat Tarhan Kitabevi, bir tribünlü stadyum, Akdeniz Spor Kulübü, Kızılay, Hava ve Çocuk Esirgeme Kurumu gibi kuruluşlar belirtilmektedir.

Çalışmada şehirdeki doktor, diş hekimi ve avukatlar da isim isim sayılmaktadır ki, sayıları bir elin parmaklarını geçmemektedir (Orak 1946, 343-3444).

"Folkloru" başlığı altında da yine şehrin bu bakımdan zengin olduğu belirtilmekte, halkın adetlerini, gelenek ve göreneklerini, kahramanlıklarını yakımlar, koşmalar, maniler, masallar, destanlar yoluyla anlattığı belirtilir. Pehlivan güreşleri, meydan oyunları, deve güreşleri, at yarışları, ok, yay ve cirit oyunları ilin ananesi olarak zikredilir. Ayrıca Antalya manilerinden birisi güftesi ve bestesiyle, notaya alınmış olarak aktarılır: "Minarede ezan var/gül bahçede gezen var/Akseki'nin içinde /gün görmedik güzel var" (Orak, 1946, 345).

Şehrin yetiştirdiği önemli şahsiyetler, milletvekilleri, sağlık durumu, içme suları, 1şıklandır- 
ması anlatılır. "Işık Durumu" başlığı altında verilen bilgiler de o günün Antalya şehrini anlamak bakımından önemlidir: Fener mevkiindeki şelalelerden alınan kuvvetle işleyen Belediye'nin elektrik santrali şehrin en kenar sokaklarına kadar elektrik vermekte, her taraf aydınlatılmakta ve şehir bol ışığa malik bulunmaktadır (Orak, 1946, 345). Şehrin muhabere (iletişim) vasıtaları belirtilirken, şehir içinde ticari telefon olmakla birlikte şehirlerarası telefon görüşmelerine henüz açılmadığı kaydı düşülmüştür.

1946 Antalyası'nda eğlence mesire yerleri de sinırlıdır. Bir sinema vardır. Esaslı bir sinema yapılması düşüncesi de görüşmecilere aktarılmıştır. İnönü Parkı başta olmak üzere deniz kenarındaki Park Gazinosu ile altında yer alan yüzme havuzu, Tophane Gazinosu, Çocuk bahçesi, şehrin doğusuna düşen şelaleler, $10 \mathrm{~km}$. mesafedeki Lara Plaj1, $3 \mathrm{~km}$. batıdaki Konyaaltı Plajı, Peşe Kavakları ve Şarampol Mevki halkın rağbet ettiği mesire ve eğlence yerleri arasında belirtilir. Yaz mevsimlerinde ise halkın Korkuteli, Elmalı ve Isparta'daki yaylalara gittiği kaydedilmektedir.

Çalışmanın Antalya'yı ilgilendiren diğer sayfalarında ise tek tek ilçeler kısa bilgilerle ama benzer bir sistematikle ele alınmıştır. Yine ilçelerin o günlerdeki fotoğraflarına da yer verilmiştir.

Antalya İli'nin başında ayrıca şehrin bir fiziki haritası da renkli olarak yayınlanmıştır.

Çalışmada bugün Türkiye'nin en önemli turizm merkezlerinden birisi olan Antalya'nın bu özelliğine dair en ufak bir bilgi yoktur. Keza otelleri ile ilgili de bilgi verilmemiştir.

\section{Sonuç}

Çalışma bize 1946 yılının Antalyası'na ilişkin ilginç ve önemli bilgiler aktarmaktadır. Kuşkusuz ki şehir tarihi bakımından pek çok alanda mukayeseli çalışmalar üretmek için burada yer alan veriler dikkate alınacak bir kaynaktır. Ne yazık ki, yayınlandığı yıllarda ülkenin içinde bulunduğu sosyo-ekonomik ve kültürel şartlar bu zor ve zahmetli bir çalıșmanın ürünü olan eserin yeterince anlaşılmasını ve değerlendirilmesini engellemiş; öyle ki, çok talihsiz gelişmeler müteşebbisinin iflasına yol açmıștır. Elimizde çalışmanın 14 ili kapsayan kısmı kalmıștır. Bu illerden biri olmakla, değerli bir veri kaynağına sahip olduğunu düşündüğümüz Antalya’ya ait aktarılan bilgilerin bazılarını bugünkü verilerle mukayese ettiğimiz zaman, aslında yakın zaman olarak ele alacağımız bir sürecin şehre etkilerini görebilmemiz de mümkün olmaktadır.

Sözgelimi o yılların 256 binlik nüfusuna mukabil, 2010 y1lı adrese dayalı kayıt sistemi verilerine (TÜIK) göre Antalya şehir merkezinde 502.491 erkek, 498.827 kadın olmak üzere toplam 1.001.318 kişi yaşamaktadır. Nüfus büyüklüğü bakımından Türkiye’nin 7. ilidir. Özellikle, 1970'li y1llardan itibaren ciddi bir iç göçe maruz kalan Antalya, 1980'li yıllarla birlikte turizm tesisleri ile yoğun bir işgücü akımına uğramış, akabinde yurtdışından da bu şehirde yaşamak ve yerleşmek üzere gelen yabancı göçü almıştır. Şehir yılda 8-10 milyon civarında yabancı turist çekmektedir. Şehir, içinde yaşayan insanlar için bile sınırlı bir eğlence ve mesire imkânı sunarken, bugün dünyanın en önemli doğa ve kültür turizm merkezine dönüşmüştür. Tarımsal üretimde yine Antalya Türkiye'nin en önde gelen illerinden birisidir. Antalya Ovası, ile tarımsal potansiyel ve ekolojik uygunluk açısından tarımda önemli bir yere sahiptir. İl topraklarının beşte birinde tarım yapılmaktadır. Antalya'da tarım yapılan yerleri kıyı kesimi ve kıyıdan uzak kesimler olarak ayırırsak kıyı kesiminde turunçgiller, muz, avakado gibi tropikal bitkilerin yanında ciddi bir sera tarımı da yapılmaktadır. Kentin hızlı gelişmesine paralel bir süreç yaşayan tarım sektörü kendi yapısında da derin değişimlere uğramıştır. 1970 yılında nüfusun dörtte üçü tarımsal sektörlerden geçiniyorken bu oran günümüzde \% 40 'lara düşmüştür. Ancak günümüzde ormana, ağaç endüstrisine dayalı bir imalat sanayinden söz etmek mümkün değildir. Şose yollardan, yetersiz ulaşım imkânlarından, yurtiçinden ve yurtdışından milyonlarca insanın mobilitesine imkân veren bir ulaşım ağına ulaşılmıştır. Şehre ulaşım ve şehirden ilçelerine ve ülkenin diğer bölgelerine ulaşım günümüzde havayolu, karayolu ile kesintisizdir. Demiryolları projeleri coğ- 
rafi şartlar nedeniyle geliştirilememekle birlikte, hep gündemde olmuştur.

Sonuç olarak, 1940'lı yıllarda Antalya'nın giderek modernleşen bir kent görünümü sunmakla birlikte, geleneksel topluma ilişkin bazı karakteristikleri de bünyesinde sürdürmekte olduğu söylenebilir. Karayolu, demiryolu ve deniz yoluyla gerçekleştirilen ulaşımın ağırlıklı olarak motorlu araçlarla ve organik temelli olmayan enerji kaynaklarının kullanımıyla sürdürülmesini, imalat sürecinde makineye dayalı yeni teknolojilerin kullanılmasını, şehir aydınlatılmasında elektrik enerjisinden yararlanılmasını, dış dünya ile ticari ilişkiler kuran ve endüstriyel mal üretimiyle iştigal eden bir müteşebbis grubuna ve zihniyetine sahip olmasını, eğitim-kültür kurumlarıyla ve iletişim imkanlarıyla birlikte giderek modernleşmekte olan bir kentin göstergeleri olarak değerlendirebiliriz.

Türkiye Kılavuzu adlı bu çalışmanın araştırmacılar için iyi bir veri kaynağı olarak bütünüyle yeniden ihyası kuşkusuz ki çok yararlı olacaktır, ancak en azından Antalya gibi, ekonomik ve kültürel yönden imkânları geniş bir il için üniversite, belediye veya valilik tarafından ilgili bölümüyle değerlendirilmesi şehir tarihi için önem arz edecektir.

\section{KAYNAKÇA}

Ahmad, F. (1999). Modern Türkiye'nin Oluşumu. Çev. Yavuz Alogan. İstanbul: Kaynak Yayınları.

Anderson, B. (1995). Hayali Cemaatler: Milliyetçiliğin Kökenleri ve Yayılması. Çev. İskender Savaşır. İstanbul: Metis Yayınları.

Ankara Ticaret Odası (ATO), (1936), no: 363. Hüseyin Orak'a ait evrak ve oda kaylt dosyası. Ankara.

Bauman, Z. (1996). Yasa Koyucular ve Yorumcular. Çev. Kemal Atakay. İstanbul: Metis Yayınları.

Belge, M. (2011). Militarist Modernleşme. İstanbul: İletişim Yayınları.

Karaveli, O. (2006). Görgü Tanı̆̆ -Bir Gazeteci'nin Siradışı Anıları. İstanbul: Pergamon Yayınları.

Erdoğan, İ. (2000). Kapitalizm Kalkınma Postmodernizm ve Iletişsim. Ankara: Erk Yayınları.

Ergüder, Ü. (1991). Türk Toplumunun Değerleri. İstanbul: TÜSİAD Yayınları.

Georgeon, F. (2006), Osmanll-Türk Modernleşmesi (1900-1930). İstanbul: Yapı Kredi Yayınları.

Giddens, A. (2004). Modernliğin Sonuçları. Çev. Ersin Kuşdil. İstanbul: Ayrıntı Yayınları.

Karpat, K. (2002). Osmanlı Modernleşmesi: Toplum, Kurumsal Değişim ve Nüfus. Çev. Akile Z. Durukan, \& Kaan Durukan. Ankara: İmge Kitabevi Yayınları.

Karpat, K. (2006). Osmanlı'da Değişim, Modernleşme ve Uluslaşma. Çev. Dilek Özdemir. Ankara: İmge Kitabevi Yayınları.

Kasaba, R. (1998). Eski ile Yeni Arasında Kemalizm ve Modernizm. Ed. Sibel Bozdoğan, \& Reşat Kasaba. Türkiye'de Modernleşme ve Ulusal Kimlik, 12-29. İstanbul: Tarih Vakfı Yurt Yayınları.

Kıray, M. (1982). Toplumbilim Yazıları. Ankara: Gazi Üniversitesi Yayınları.

Orak, H. (1946). Türkiye Kllavuzu. İstanbul: İbrahim Horoz Basımevi.

Orhon, Orhan Seyfi. Yeniçağ Mecmuas1 (06.04.1946).

Pirenne, H. (1994). Ortaçağ Kentleri. Çev. Şadan Karadeniz. İstanbul.

Evinç, V. Mühim Bir Eser. Türk Dili Gazetesi. (28 Nisan 1946).

Şengül, T. (2012). "Türkiye'nin Kentleşme Deneyiminin Dönemlenmesi”. Ed. Faruk Alpkaya, \& Bülent Duru. 1920'den Günümüze Türkiye'de Toplumsal Yapı ve Değişim, 353-403. Ankara: Phoenix Yayınları.

Tekeli, İ. (1998). "Bir Modernleşme Projesi Olarak Türkiye'de Kent Planlaması". Ed. Sibel Bozdoğan, \& Reşat Kasaba. Türkiye'de Modernleşme ve Ulusal Kimlik, 136-153. İstanbul: Tarih Vakfi Yurt Yayınları.

Ünsal, A.(1998). "Yurttaşlık Zor Zanaat". 75 Yllda Tebaa'dan Yurttaş'a Doğru. İstanbul: Tarih VakfiTürkiye İş Bankası Yayınları.

Yüksel, M. (2004). Modernite Postmodernite ve Hukuk. Ankara: Siyasal Kitabevi Yayını. 


\section{Dergi ve Gazeteler}

Akşam Gazetesi. (3 Mart 1946).

Ankara Gazetesi. "Başkentin Kilavuzu”. (30 Mart 1946).

Aydın Gazetesi. “Türkiye Kılavuzu”. (30 Haziran 1946).

Cumhuriyet. (2 Nisan 1946).

Son Posta. (03 Mart 1946).

Son Posta. (31. Mart1946).

Son Posta. (03 Nisan 1946).

Son Telgraf Gazetesi. (27 Mart 1946).

Pazar Gazetesi. (01 Nisan 1946).

Türk Yolu Gazetesi. (12 Nisan 1946).

Türkiye Kılavuzu Hakkında Broşür 1.1946. Ankara.

Ulus Gazetesi. “Çok Faydalı Bir Eser”. (20 Mart 1946).

Ülkü Dergisi. (16 Nisan 1946).

Vakit. (30 Nisan 1946).

\section{Görüșmeler}

Orhan Karaveli, (Gazeteci -Yazar Orhan Karaveli ile yapılan görüşme), İstanbul, 14 Haziran 2011.

A. Sahavet Özbay, (A. Sahavet Özbay ile yapılan görüşme), Ankara, 24 Haziran 2011.

\section{Internet Erişimleri}

http://www.kenthaber.com/ic-anadolu/eskisehir/Kimdir/iz-birakan/yavuz-abadan, (Erişim: 25.02.2012). http://www.kimkimdir.gen.tr/kimkimdir.php?kim=hasanaliyucel, (Erişim: 24.02.2012).

http://www.iletisim.com.tr/ki\%C5\%9Fi/mustafanihat\%C3\%B6z\%C3\%B6n565.aspx, (Erişim:25.02.2012). http://www.turkuler.com/tgv/ferruh.asp, (Erişim: 25.02.2012).

http://zehirlenme.blogspot.com/2010/10/balneoloji-ve-balneoterapi-nedir.html, (Erişim: 24.02.2012). 
